\title{
ORNAMENTAL PLANTS IN THE SOUTHERN REGION OF ALBANIA CONTAMINATED BY ENTOMOPARASITES OF U/ ORDER COCCOINEA, INSECTA CLASS
}

\author{
Lavdi Hasani \\ Department of Biology \\ University "Eqrem Çabej" \\ 30 Rruga Studenti, Gjirokastër, Albania, 6000 \\ hasanilavdi@yahoo.com
}

\begin{abstract}
In this paper, one of the most specific groups of plant entomologists, that of the U/Order Coccoinea Class Insecta is taken into analysis. Below it is seen important to identify the problems of infections of a variety of ornamental plants, found in the Southern Region of Albania, precisely by this group of pests. The role of the quality of the natural environment in our health has recently taken tremendous priority in the context of the contamination of all forms in the wild nature and especially those in the air. Precisely, to increase the quality of our life, the establishment of major parks with a truly significant green space per unit of population, is one of the current main objectives of each country. In these conditions, those environments are pretty rich in a variety of plants that, in addition to the functional values of environmental creativity, also have many aesthetic values with relaxing power and positive effects on our physical and mental health This type of plants is represented not only by those that are cultivated directly in the nature, but also by those that are planted and cultivated in greenhouses, which from time to time we take them out to realize the required decorations and compositions, asked to cover the needs of the parks. The healthier these components of this environment are, the more effective is their role on our personal health. For this reason it is equally important to recognize the dangers that threaten this vegetation by disabling its main function, for which we, as citizens, are interested, due to the need of our health, to have it in the highest efficiency. On this basis arose the idea of a comprehensive study on the above group of insects, which in a form or another constitute some of its main pests. These insects, as a specific group of pests that feed on plant lymph, not only dry out the plant, but also transmit to it a series of viral diseases, leading the plant to complete degradation. Most of them spend the winter (one of the most delicate periods for their survival) as parasites on them. We show below, which of these entomophytes is found in this group of plants in the region in question. It is also shown, which of the analyzed plant species emerges as the most frequented by this group of pests. We also identify the prevalence of this pollution in both variety and percentage. On the basis of the analysis, the question is also what is the distribution of plant species encountered, at different altitudes above the sea level? The paper contains, figuratively, a series of morpho-defining characteristics of the representatives, mentioned in this paper. As will be seen in the following material, the truth is that this specific group of ornamental plants, part of the relaxing parks around the world, in our country turns out to be contaminated by a large number of these parasites. This shows that in order to carry out quality work in this direction, we must not leave without considering the role of these pests in this process. Thus, we will be able to control the quality and function of our recreational environments in the role, for which we realize them. For this reason, detailed data are given below. We have identified these parasites in about 15 (fifteen) species of these ornamental plants, taking into account that parks in our country are not valued for the size of the area, as in an inferior and small country. In this material we have identified the number and dynamics of parasites according to each plant and also according to their distribution in areas with different altitudes above the sea level. We also give a comparative report on the frequency of vulnerability of the various plants by representatives of these pests. Summarized in a table, we have given for each pest the plant variety that it frequents, noting, in which plant organ this parasite was most commonly found during our research. As it is a group with annual activity on the plants, we have data for each month that we have met them on this vegetation and for each plant organ, where they were met (in leaves, on stalks or even the fruit itself). Regarding the degree of the damage that they cause to the plants, given the many harmful valences they show, not all belong to the category of the very dangerous pests. Some enter the minor pests that are mostly caused by overlapping other diseases, some others into the normal pests and a more specific group enters the category of very powerful pests, the risk of which is maximized with other additional effects. These and other information are given in table Number 1 (one), with the required symbolism.

Since this group of plants is the environmental generator, where we live and work, the work in question takes on practical importance and value.
\end{abstract}

Keywords: Ornamental plants, parasites, pollution, pests, varieties, spread, micropreparations, region, damage, pigids.

DOI: $10.21303 / 2504-5695.2021 .001752$

\section{Introduction}

With the group of insects, belonging to the Suborder Coccoinea, we have been dealing continuously by highlighting their role and "values" as pests. Working with them is a bit not easy for its spe- 
cifics both in terms of nutrition as well as in terms of microscopic shape and size of their body. There are several strong and specialized species, associated with a certain type of plant, from which they get their name as: Lepidosaphes ficus Sign (affecting the fig) or Saisetia oleae Bern (affecting the olive) etc. There are also microscopic shapes (most parts) and shapes that can be easily observed [1-6].

In both cases the determination of the representatives of the U/Order is difficult, especially with microscopic forms. The damage they do to the plant consists in the reduction of their nutrient, in the deformation of the twigs and leaves of the plant, they reduce the photosynthetic profitability and they also transmit viral diseases to it.

In ornamental plants they become the main factor of various fungal plant diseases. In this way, contaminated plants are threatened by several pathogenic hazards simultaneously.

However, the level of damage is not the same for all types. There are strong direct pests, common pests and milder forms of parasitism (indirect pests) [7-15], etc.

By identifying the damage of these parasites on ornamental plants, we help the field specialists in their breeding in all our relaxing environments. So we also affect our quality of life as these plants are what beautify our living environments and relaxation parks.

\section{Material and methods}

The material, we collected from various plant organs, was stored directly in test tubes with alcohol above 75o. In the field we also carried out the labeling with all the required elements (Fig. 1). This canned material based on the methodologies, given in lit. [16], was further processed in the zoology laboratory of the Department of Biology of the University "E. Çabej ", Gjirokastër. We released samples from their wax coatings by treating them with $10 \% \mathrm{NaOH}$ solution and heating. Then we cleaned them with plenty of water, rinsing them five times and finally leaving them in it for 24 hours. Then leave them for 10-15 minutes in $70^{\circ}$ alcohol and then put them for coloring in Fuchsia solution for 3-24 hours.

To fix their color, we put the samples in alcohol that gradually increases the concentration, for $10-20 \mathrm{~min}$. time at each alcohol concentration, from $70^{\circ}$ to $90^{\circ}$ and finally to $96^{\circ}$. Carefully and under two eyes, the samples were extracted from there and based on the above methodologies, the material was processed until the formation of their permanent microscopic preparations. Based on the literature used, we decided which would be the main elements for their definition. For macroforms we have observed the complete morphology while for microscopic ones we have relied precisely on the composition of their pigids. By observing them under a microscope based on the determinant switches, given in [17, 19-24], we were able to realize their determination down to the species. At working binocularly, we also made a series of sketches on the construction of the pigids of each species, as well as in the more macro cases of the whole view of the living thing.

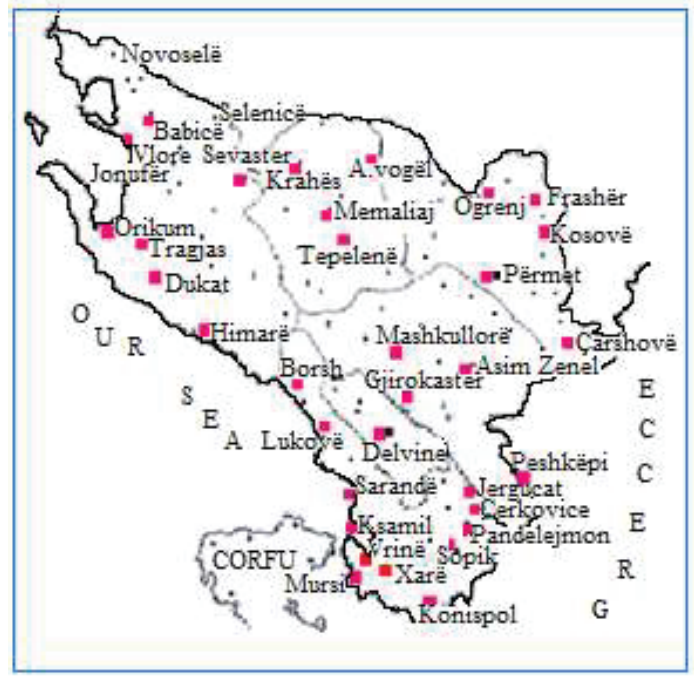

Fig. 1. Checkpoints, set up in the field 


\section{Results and discussions}

As it is seen in Fig. 2, decorative plants, contaminated by this group of insects have been found in only four/six regions, taken into analysis. Among these checkpoints, as the map also shows, the most affected region is Saranda, followed by Vlora and then Gjirokastra. The amount of damaging Coccides, found in the whole region, in the morphologic determinative plan, is presented in Table $\mathbf{1}$ and in Fig. 5, 7, 8 as follows. Data, according to the possibility of these parasites of being found, are represented in Fig. 4 as follows: abutilone and castor are mostly frequented by these parasites, seen from their spread spectrum in different heights above the sea level $(4-220 \mathrm{~m})$. The plant of laurel $(4-200 \mathrm{~m})$, rose etc. In restricted or low heights have been found the plants of greenhouses. In Fig. 6 (down) it is obvious, that the plant, most frequented and preferred by many types of parasites, is rose and oleander with $18 \%$ of all the parasites, encountered in the whole region. Then follows castor with $14 \%$ of all the types, laurel with $12 \%$ etc. less affected are the plants of aloe, lime (tilia), imiscus, pilea and palm. Graphically, this contamination is represented in Fig. 3. The whole gathered material in land, after being elaborated in lab according to the methods, described in literature, $[25,26]$, was formed in microscopic permanent preparations.

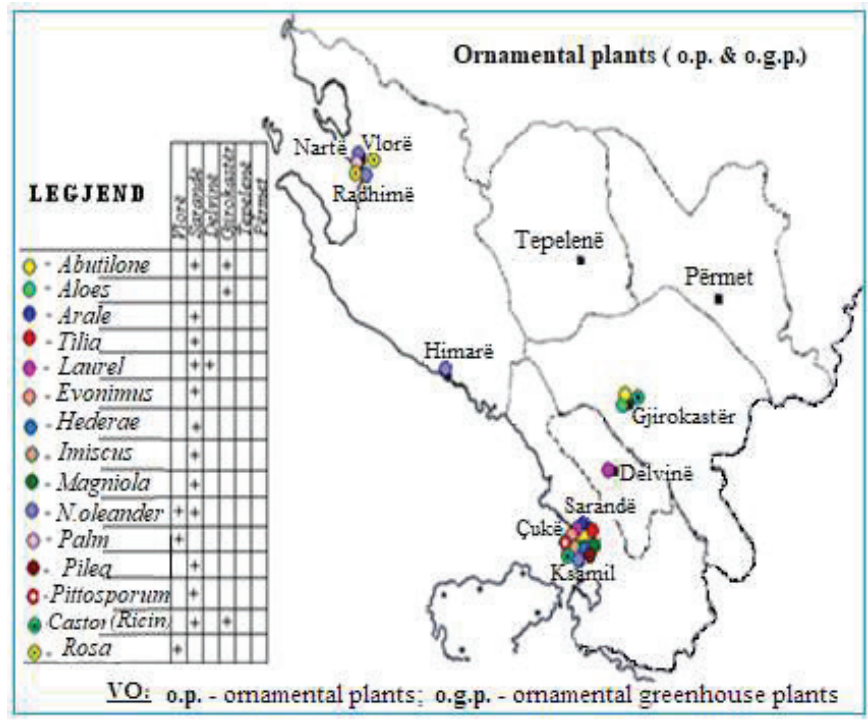

Fig. 2. Stages of infected plants

After that, with the help and definitions, used in literature [18, 25, 27, 28], the determination of the types was made possible. From the work under binoculars as a very difficult and important task, there were also compiled the morphological sketches of the animal itself, especially of the parts with special determinative importance, such as their pigid, where the majority of the waxen glands, anal rings, spikes in the marginal way, parts $(L 1, L 2$, etc), crests $(c)$, hairs $(h)$, denzarce $(d)$, parafiza $(p)$ etc. are placed (Fig. 5).

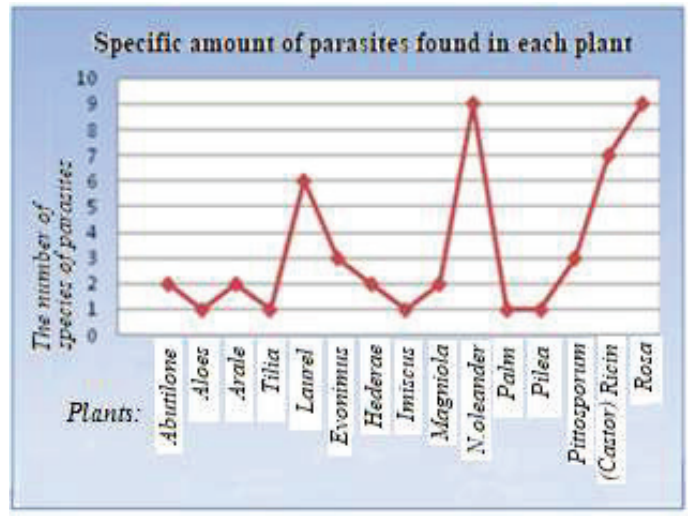

Fig. 3. The number of species of parasites, found in each plant 


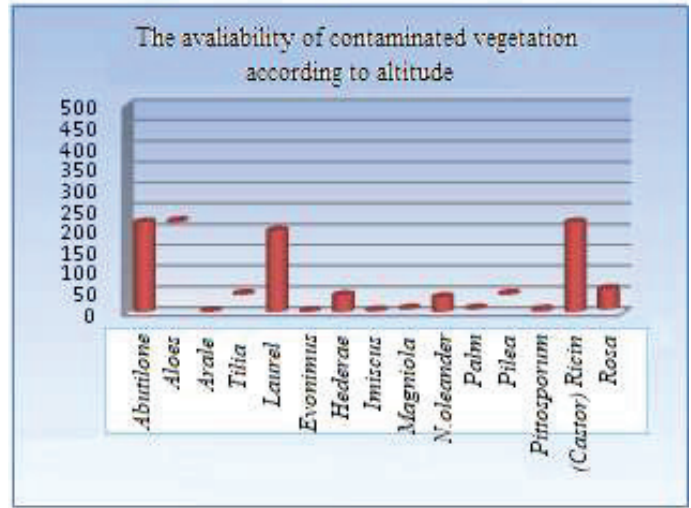

Fig. 4. Distribution of infected vegetation by altitude

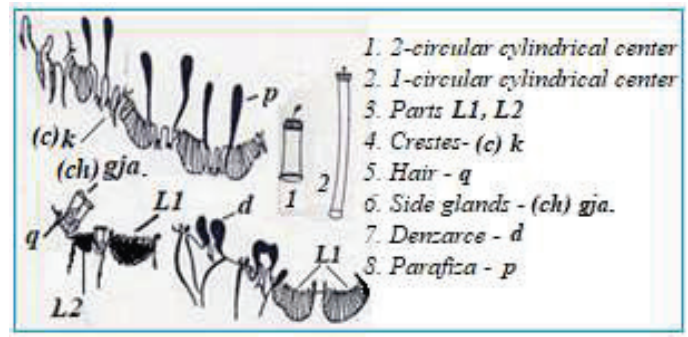

Fig. 5. Determinant of the pigid elements

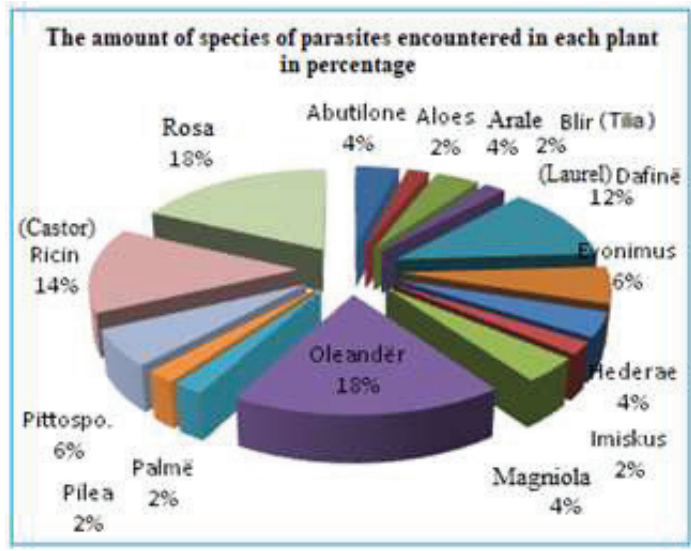

Fig. 6. Proportion of pests in each plant species

The elements, placed mainly in the area of pigid, have a special determinative importance not only for their forms variety that differ among others, but also for their placement way, symmetry preservation in both sides of the pigid, their measure and combination that create. The pigid glands can appear in cylindric but also fungal, tub, disc, bottle, multi cellar, three-five cellar forms etc. It is exactly this elements variety that should be taken into consideration for the realization of a determination as correct as possible. All these sketches that are carried out with binoculars are represented in the pages with images that associate the following Table $\mathbf{1 .}$

VO:

$A$ - The plant organ, where the harmer is found $(x)$

$-(s)=$. stem; $-(l)=$. leaf; $-(f)=$. fruit.

$B-$ Explored regions

$-V=$ Vlorë $;-G J .=$ Gjirokastër; $-T .=$ Tepelenë; $-S .=$ Sarandë; $-P .=$ Përmet; $-D .=$ Delvinë. 
$C-$ The months of the year $[x]$

$-j,-f,-m \mathrm{c} h,-p,-m,-j n,-j l,-a g,-s,-o,-n,-d$.

$D$ - Damage

$-($ Name $)=$ non-harming direct species;

$-\left({ }^{*}\right.$ Name $)=$ harming direct species;

$-(* *$ Name $)=$ strong, harming direct species.

Table 1

The variety of parasites encountered in each plant type

No. Species name $\quad$ The plant where it is found

$1 \quad$ Coccus hesperidum L. (k.gj) [sh, m, j, ms]

2 Coccus pseudomagnoliarum Kuw. (k.gj, f)[sh, m, j, ms]

*Saissetia oleae Bern. (k.gj) [m, j, sh]

*Parlatoria oleae Colv. (k.gj) [m, p, ms]

*Parlatoria cinerea Hadd. (k.gj) [m, j]

*Aonidiella aurantii Masc. (k.gj) [m, ms]

*Aonidiella aurantii rac citrina Coq. (k) [p] *Aonidiella taxus Leone. (k) [p]

*Aonidia lauri Bouche (gj) [m]

*Ephedraspis ephedrarum Indgr. (gj) [m]

*Pinnaspis aspidistrae Sign. (k.gj) [m]

**Unaspis euonymi Comst. (k.gj.) [m]

*Unaspis citri Comst. (k.gj) [m]

*Lepidosaphes beckii New. (gj) [j]

Aspidiotus spinosus Comst. (gj) [j, ms]

*Pseudococcus citri Risso. (gj) [m]

*Pseudococcus gahani Green. (k.gj) [m]

*Pseudococcus maritimus Ehr. (k.gj) [m]

*Pseudococcus adonidum L. (k.gj) [m]

*Pseudococcus rectus Borchs.(k.gj) [j]

*Pseudococcus expressus Borchs.(k.gj) [j]

*Aspidiotus nerii (hederae) Bouch. (Vall.) (gj) [sh, m, j]

*Hemiberlesia rapax Comst. (k)[ms]

Hemiberlesia lataniae Sign. (k.gj) [ms]

*Hemiberlesia cyanophylli Sign. (k) [ms]

*Chrysomphalus aurantii Mask. (gj) [m]

*Chrysomphalus ficus Ashm. (k) [j]

*Chrysomphalus dictyospermi Morg. (k) [j]

*Icerya purchasi Mask. (k.gj) [m, j]

*Eriopeltis bichtensteinii Sign. (k.gj) [j]

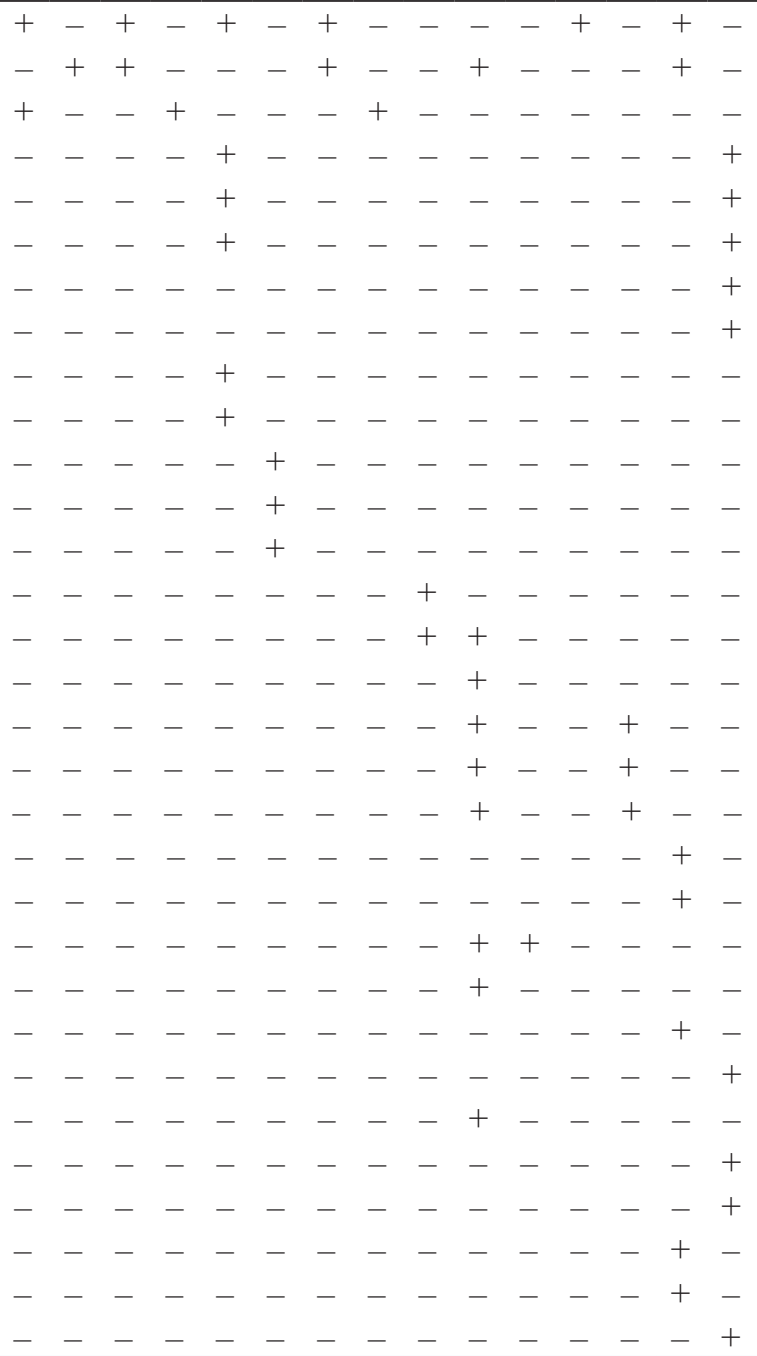

*Pseudaulecaspis pentagona Targ. (k) [p] 
Based on the symbols, represented in the end of this table, we see that from the group of plant parasites, only one of the species encountered is a strong direct harmer (**Unaspis euonymi Comst. (k.gj.) [m]), the others are direct harmers and a small amount are indirect harmers $(\mathrm{Coc}-$ cus hesperidum L. (k.gj.) [sh]), (Coccus pseudomagnoliarum Kuw. (gj.) [sh]), (Aspidiotus spinosus Comst. (gj.) [j]), dhe (Hemiberlesia lataniae Sign. (k.gj.) [ms]).
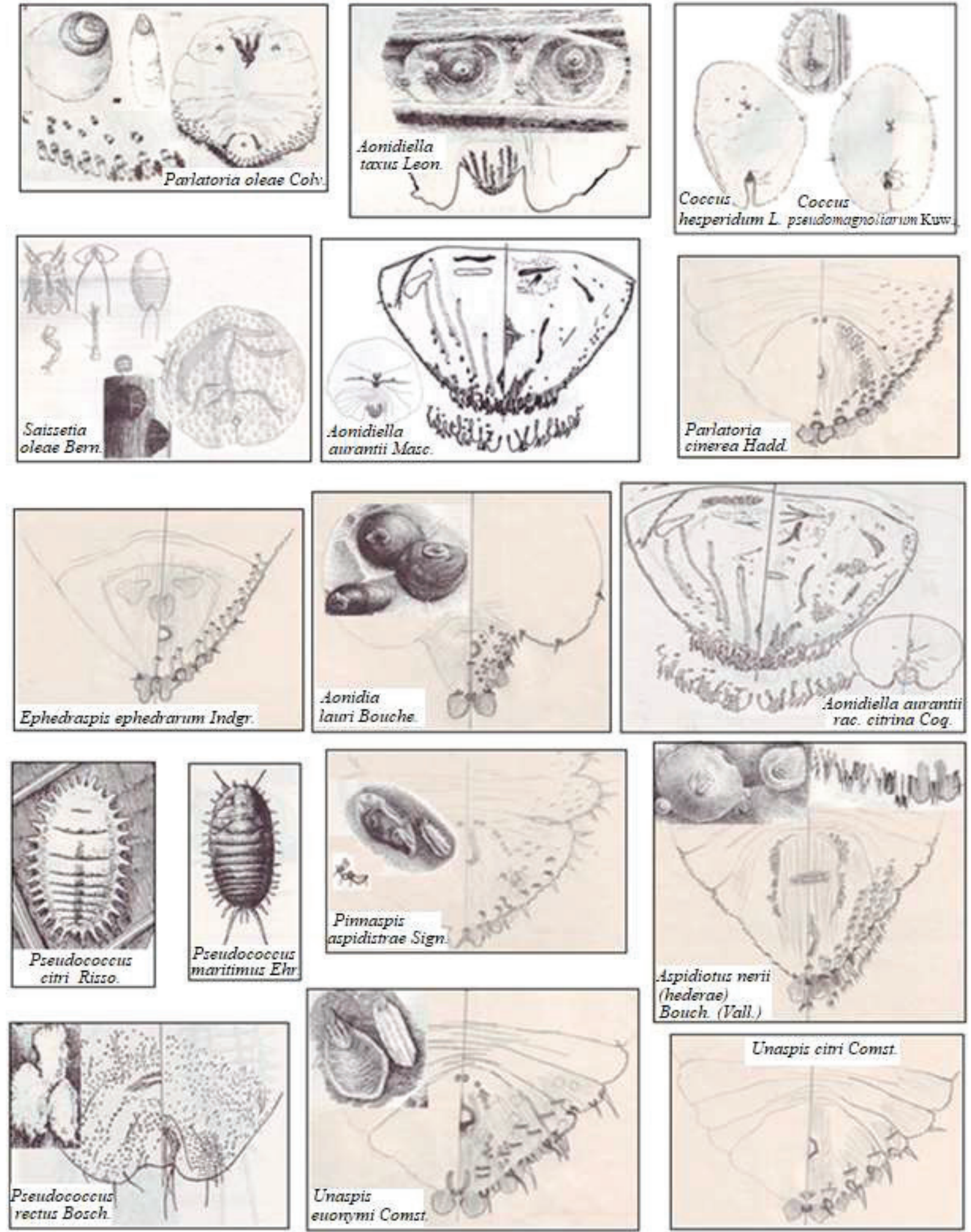

Fig. 7. Sub-ocular view of the pests in a microscope 

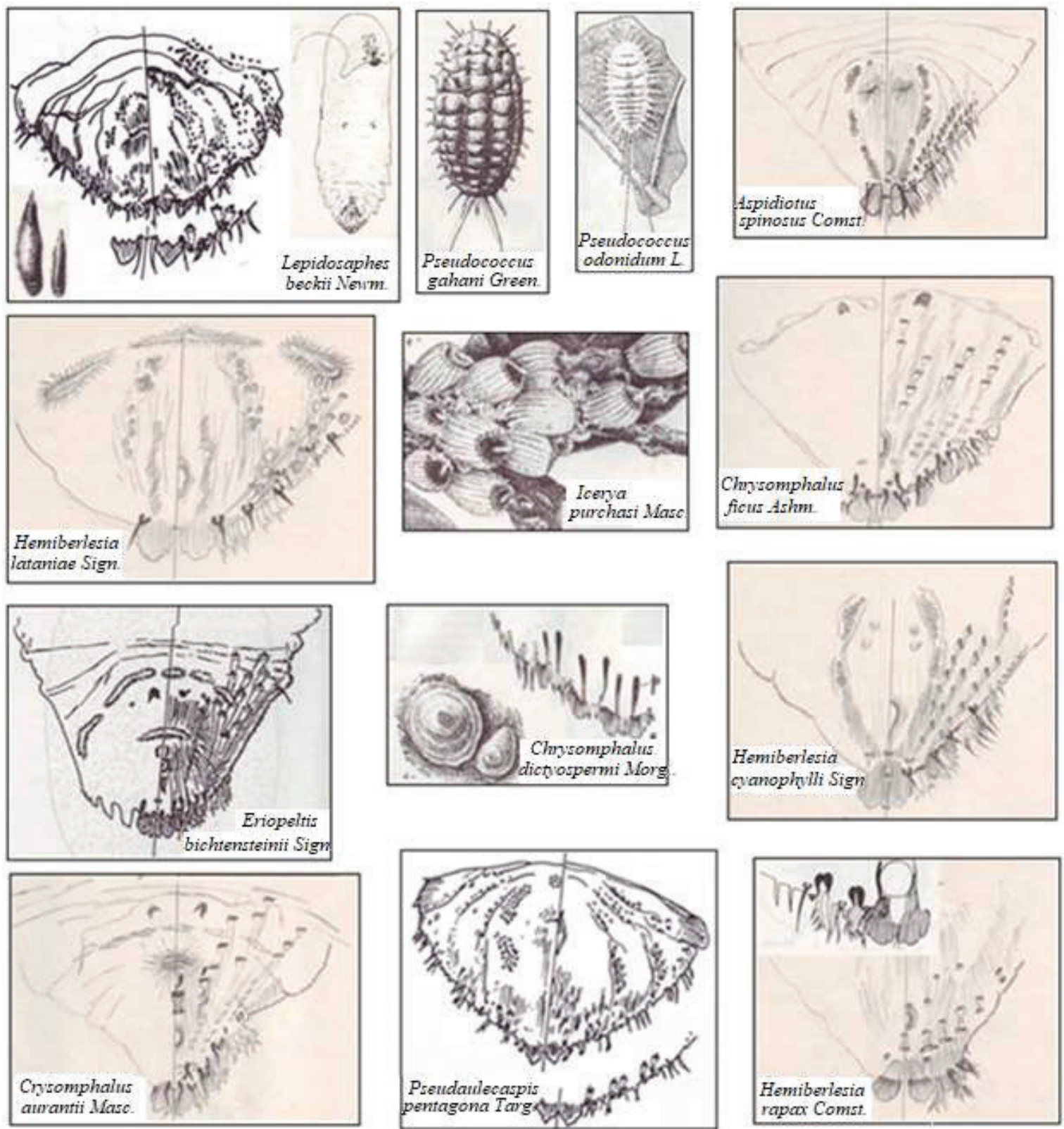

Fig. 8. Sub-ocular view of the pests in a microscope

\section{Recommendations}

1. As it was analyzed before, it must be taken a special care on the greenhouse plants, affected by parasites, as the microclimate, created in it, is in favor of the parasites despite the area with continental climate.

2. The plants must be held under control during winter even though we think that because of the cold the parasites are not active or fall in pause.

3. In the case of this plant group, the chemical fight is acceptable as it is not a consumable plant.

4. In some cases, the fight against consists in painting of the new stems with diesel, so the young larva will not have any chance to hook and winter there.

\section{Conclusions}

Based on the above data we reach these conclusions:

1. As it is also seen in Table 1, in the whole region being analyzed, we have found in total 31 kinds of parasites of N/Order Coccoinea, of which one represents a strong direct harmer ((**Un- 
aspis euonymi Comst), 26 represent direct harmers (the majority) and only four kinds represent indirect harmers (Coccus hesperidum L, Coccus pseudomagnoliarum Kuw., Aspidiotus spinosus Comst., dhe Hemiberlesia lataniae Sign.))

2. All the decorative plants, both cultivated in nature and greenhouse, are contaminated by this group of harmer (Fig. 2, 4).

3. These parasites do not prefer the same plants. The most preferred by them are N.oleander and rose with 9 types, castor with 7 types, laurel with 6 types and so on as well as the plants with one type, such as palm, lime aralia etc. (Fig. 3). This information is represented in percentage of the total of harmers in Fig. 3. The 9 types, found in the plants with the most infecting species, represent $18 \%$ of the total and so on. This preference is thought to be caused by the preference for the food that these parasites have on the plants lymph.

4. From the whole region being analyzed we see that the most contaminated plants were found in Saranda, then in Vlora and further in Gjirokaster and Delvina. We do not have found any in the regions of Tepelena and Permeti. Given the fact that in Gjirokaster we have found contamination in greenhouse plants, we reach the conclusion that the continental spread of these parasites is much restricted. The possibility of non-cultivation of these kinds of plants is not excluded (Fig. 1).

5. In some plants we find their contamination in a wider range of their spread in high levels above the sea and in some others we do not. Contaminated plants of the abutilone or castor have been found in territories $4 \mathrm{~m}$ above the sea level until $220 \mathrm{~m}$ above the sea level. These plants are followed by laurel, rose and hederae etc.

Being that the number of the parasites, found in these plants, is smaller than in the other plants, we reach the conclusion that the parasites, frequenting these plants, are the most adopted and connected to the plant and have great climate independence as far as their territorial spread is concerned (Fig. 4).

6. The harmers affect in general all the plant organs (stem, leaf, fruit), but some parasites can be found only in one organ, such as the leaf, which is the most typical (Table 1).

\section{References}

[1] Arhangelskaja, A. D. (1974). Koksidi arjednjej Azii Tashkjent. Moscow (Leningrad).

[2] Balashovski, A., Mesnil, L. (1935-1936). Les insektes. Nusibles auks kultivees Vol. I-II. Paris.

[3] Baçi, M. (1954). Dëmtuesit kryesor të kulturave të arave e atyre frutorë. Tiranë.

[4] Borhksenius, N. S. (1949). Fauna SSSR. Nasjekomij e hobotni. Vol. VII Pogotr. çjervjeçij i shçitovki (koksoidea) sjemjejstvo muçnistije çjervjeçi (Pseudokoksidae). Moscow, 384.

[5] Hasani, N. L. (1997). Koksidet. Tiranë.

[6] Illjustrirovanij spravoçnik po vreditjeljam i boljeznjam vnjeshn jevo karatina (1948). Minihsterstvo Sjellskovo Horjajstva SSSR, Otdjell po - Karantini Sjelskohozjajstbjennih Rastjenij, Çentralnaja Llaboratorija po Karantini Sjelskohozjajstbjennih Rastjenij. Mocow.

[7] Grafton-Cardwell, B. (2002). Stages of the Cottony Cushion Scale (Icerya purchasi) and its Natural Enemy, the Vedalia Beetle (Rodolia cardinalis). doi: https://doi.org/10.3733/ucanr.8051

[8] Borhksenius, N. S. (1957). Fauna SSSR. Nasjekomije hobotni. Vol. IX Pogotr. çjervjeçi i shçitovki (koksoidea) sjemjestvo podushjeçnshçi i llozhnoshçitovki (koksidae). Moscow.

[9] Çiça, A. (1963). Kultura e kumbullës. Tiranë.

[10] Çeloaliaj, Q. (1987). Speciet e breshkëzave të përhapura në agrume në zonën e Vlorës e Sarandës. Instituti i agrumeve dhe ullirit. Vlorë.

[11] Gaxho, S. (1965). Kontribut në studimin e breshkëzës së kuqe të agrumeve. (Chrysomphalus dictyospermi Morg.) dhe mbi disa prova të luftimit të saj. BUSHT. Seria e Shkencave Natyrore No. 3. Tiranë.

[12] Murra, X. (1960). Vëzhgime mbi breshkëzën e fikut (Ceroplastes rusci L.). BUSHT. Seria e Shkencave Natyrore No. 3. Tiranë.

[13] Kaltani, T., Stani, A. (1973). Sëmundjet dhe dëmtuesit e ullirit, agrumeve, fiqve, kajsisë dhe nespullës. Tiranë.

[14] Murra, Xh. (1981). Main harmers of the cultures. Tiranë.

[15] Nishani, T. (1980). Flowers diseases. Tiranë.

[16] Borhksenius, N. S. (1950). Çjervjeçi i shçitovki SSSR (koksoidea). Moscow.

[17] Borhksenius, N. S. (1964). Oprjedjelitjel nasjekomih evropjejskoi çasti SSSR. Vol. I. Moscow. 
[18] Oprjedjelitjel nasjekomih evropjejskoj çasti SSSR. Vol. I. Nizshije, drjevnjekrilije, snjepolnim prjevrashçjenijem (1964). Akademija Nauk SSSR, Zoollogiçjeskij Institut. Mocow-Leningrad.

[19] Borhksenius, N. S. (1949). Oprjedjelitjel çervjeçi i shçitovki (koksoidea). Erjevan.

[20] Borhksenius, N. S. (1950). Çervjeçij i shçitovki SSSR (Koksoidea Opredjelitjeli po faunje SSSR, izdavajemije. Zoologiçjeskim institutom Akadjemii Nauk SSSR No. 32.1. Moscow.

[21] Borhksenius, N. S. (1937). Oprjedjelitjel koksid (koksidae) vrjedjashçik kulturnim rastjenijam i ljesu. Vol. II. Moscow.

[22] Borhksenius, N. S. (1973). Praktiçjeskij oprjedjelitjel koksid (Coccoidea) kulturnih rastjenij i ljesnih porod SSSR. Leningrad.

[23] Hasani, N. L. (1999). Insects definers. Çelës-Atlas. Tiranë.

[24] Rubcov, I. A. (1954). Vrjeditjeli citrusovih i ih jestjestvjenije vragi. Moscow.

[25] Borhksenius, N. S. (1950). Sbor i izuçienije çjervjeçov i shçitovok. Moscow.

[26] Borhksenius, N. S. (1966). Katalog shçitovok (Diaspidoidea). Mirovoj fauni. Moscow-Leningrad.

[27] Kosta, C. (1981). The work steps for the prepation of the entomologic micro preparations. London.

[28] Borolet, D. L. (1950). Përpunimi i breshkëzave. Lonon.

Received date 17.02.2021

Accepted date 23.03.2021

Published date 31.03.2021
(C) The Author(s) 2021

This is an open access article under the CC BY license (http://creativecommons.org/licenses/by/4.0).

How to cite: Hasani, L. (2021). Ornamental plants in the Southern Region of Albania contaminated by entomoparasites of U/Order Coccoinea, Insecta Class. EUREKA: Life Sciences, 2, 32-40. doi: https://doi.org/10.21303/2504-5695.2021.001752 